\title{
Literary characters and interdiscursivity in the novel "The Books of Jacob" by Olga Tokarczuk
}

\section{WALENTYNA KRUPOWIES}

DOI: https://doi.org/10.31577/WLS.2021.13.4.8

An attentive reading of Olga Tokarczuk's works initially leads to the rather intuitive assumption that they reveal discourses present in the contemporary social space, e.g. ethnic, eco-critical, the discourse of the excluded. These can be considered as a form of expression of her opinion on socially relevant issues (Kantner 2019, 12-13). The phenomenon of contemporary discourses penetrating a literary text also occurs in Ksieggi Jakubowe ([2014] 2019; The books of Jacob) ${ }^{1}$, and identifying them should be considered as one of the main ways to understand the work. The aim of this study is to recognize contemporary discourses, to indicate the ways they work in a literary text, whose plot developed widely in 18th-century Europe, both in the south-eastern part of the first Polish Republic (currently Ukraine) but also in Warsaw, Częstochowa and Brno, and refers to the history of the Jewish sect of Frankists. The discursive level of the work creates cognitive values, which will be an indication of the type of knowledge generated from literary discourse interacting with discourses from the extra-literary world.

Discourse has been discussed in many studies and been featured prominently in literary theory as well. However, the notion has still not been defined precisely and so, for the purposes of this study, it is necessary to specify and clarify it. Roger Fowler's sociological theory of discourse serves as a general methodological basis. His key thesis concerning literature assumes that it is understood as a discourse situated in the context of other discourses working in social space $(1989,321)$. Literature viewed as a discourse has an open character, highly interactive, linguistically heterogenic, revealing connections with other social discourses (331). It should be emphasized that literary discourse has a constitutive character ${ }^{2}$, which results in certain implications. When other discourses enter a literary work, their status becomes modified: although they still participate in social discursive exchange, they work in the discursive area of broad critical capacity. Socially approved discourse, while interacting with literary discourse, becomes vulnerable on literary grounds to critical viewing. As the Polish researcher Katarzyna Kantner insightfully surmised, following Dominique Maingueneau's findings, such critical viewing is allowed by the status of the literature and of the creator as such, i.e. exceeding the "self" of a particular author $(2019,40-51)$. Literature gains a peculiar status owing to it being rooted in social-cultural memory and its status based on word authority. The place of literature 
in community life makes it unnecessary for literary discourse to possess any additional validation, and it is the discourse that "makes community's actions reasonable". Even though it is situated above other discourses, it simultaneously interacts with them, creating varied bonds (Maingueneau 2015, 81-82).

The recognition of social discourses, an analysis of their relationality and the ways they work in the text is one of the directions towards comprehending the work, and in the case of Tokarczuk's works it is in fact the key approach. ${ }^{3}$ Identification of these discourses in literary texts and the description of the way they present themselves should be conducted with regard to the specificity of the place of occurrence. One of the forms a discourse may take is a literary character, due to the fact that a character is "a specific literary language [...], a type of a discourse" (Kasperski 1998, 16). When an external discourse appears in a literary text through a character, then he or she becomes its carrier, functioning also as "the common ground" of a discourse in literature as well as a discourse from extra-literary reality.

Social discourses make themselves visible in the text mainly at the level of the characters' and the narrator's remarks, whereas passages where the latter uses reported or seemingly reported speech have to be treated as a substitute of the discursive form of a character's activity. It needs to be highlighted that the capacity of generating discourses is widely defined by a configuration of rules and principles both uttered and untold (Zajas 2008, 274). Not only have characters' utterances been subjected to the procedures of silence and exclusion (Foucault 2002, 7), but also their interactions, imaginations, the untold assumptions of their constructions or their point of view, hidden in the narrator's comments.

The way of the literary character's existence as a discourse carrier is clearly visible in Nachman, a character in Tokarczuk's Books of Jacob who is one of Jacob Frank's closest colleagues, and also functions as a complementary narrator. His connection to two layers of text - the depicted world and the story level -, makes him an essential element of the whole work. The construction of the character is based on the relationality principle. The relationship between the two male characters, Nachman and Jacob, is based on the playing with concepts of "strong" and "weak" masculinity. Nachman as a "weak" man in relation to Jacob's hegemonic masculinity becomes a critical gender carrier. His weakness reveals itself only from one perspective: culturally accepted masculine hegemony. It appears, for example, in his exceptional gentleness and sensitivity, which reveals itself by tearfulness and other apparent qualities, which culturally refer to femininity, in addition to the withdrawn submissive attitude towards another man, mainly Jacob. He represents masculinity unadjusted to his socially and culturally assigned role. Displaced, he cannot properly play the role of a husband and father and does not fit into the frames of the model male identity. Simultaneously as a carrier of gender discourse, created as the antithesis of Jacob, Nachman's character becomes a critical comment on the imposed strict identity patterns and social-cultural roles, imposed by society. These issues become the subject of Nachman-narrator's confessions: "I have always treated my marriage as a duty towards family and tribe" (Tokarczuk 2019, 555). He yields to the pressure 
of traditional community and becomes a husband and father, though he neither feels comfortable in these roles, nor is he good at them.

To create discourses in her novel, Tokarczuk uses three characters: Asher Rubin, Jacob Frank and Molivda-Kossakovski.

\section{ASHER RUBIN AND RATIONALISTIC DISCOURSE}

One of the discourses included in Books of Jacob is rationalistic. It is supported by a clash between the time of action and the acceleration of the 18th-century European paradigm change from pre-modern to modern. Several key elements which contribute to the paradigm of modernity are accomplished in the novel. These include the loosening of bonds with traditional community as a necessary condition of individual emancipation and the building of modern objectivity, the appearance of a new picture of the world based on developing scientific knowledge, the search for rational explanations of various phenomena present in everyday and social life connected with the eradication of magical-religious thinking, and the building of a new view of the world (Habermas 2000, 9-30). They appear in the work, contributing to the paradigm of modernity, in which a special status is held by empirical science, "which takes the spell off nature and also releases cognising subject" (28). Tokarczuk provides insight into the origins of modernity by introducing Asher Rubin, a Jewish doctor who represents subjectivity, structuring the world into a scientific approach. The construction of this character in key moments has been carried out according to the development of a modern subject. Here, Asher is mainly a carrier of Western rationality in Max Weber's meaning, closely connected with modernity $(1995,83)$, though living in the eastern peripheries of the continent.

Asher's association with background characters causes the rationalistic discourse to develop unevenly and clearly appears in a few fragments of the novel. The factor that triggers this is the revelation about Asher's university education, as he studies in Italy for several years to become a doctor. After returning, he tries to work as a modern general practitioner and becomes a representative of Western rationality in a rural area, among a community living in a pre-modern world, which is categorized in a magical-religious way. His education based on empirical sciences and the choice of rationality encourages the process that changes Asher's numerous spheres of life. He seldom visits the synagogue, he functions practically outside the religious community, his identity is determined by medical training and his job rather than his background and tradition. His picture of the world also evolves, now created by acquired scientific knowledge and the monitoring of press announcements regarding consecutive scientific discoveries: "And to think: in his Berlin newspaper he was reading today, how in remote America it had been proved that thunder is an electric phenomenon and thanks to a straight wire you can protect yourself from God's anger" (Tokarczuk 2019, 869).

Asher is a lonely figure in his community, scarcely communicating with it. His solitude and silence result from an alternative way of perceiving the world. Asher as a subject constituting himself within rationality looks upon traditional community through the lens of Western logos and modernity. He takes a superior attitude and in- 
directly exposes the hidden potential of oppressiveness in the rationalistic discourse: he thinks that its members are "immersed in mystic tales, superstitious and primitive, draped in talismans, with a cunning, mysterious grin" $(2019,872)$. The world of religious Jews (and also the pre-modern world in general) is perceived by Asher as the world of the Queen of the Night from Mozart's opera The Magic Flute, which should become enlightened with reason.

Discourse is created in the course of interaction and within acts of communication, so rationalistic discourse cannot emerge from Asher's interaction with traditional community. It is not a discourse inherent in the community and it is not perceptible by the community existing in the pre-modern paradigm. In the novel, it emerges from Asher's communication with the West: the character reads the Western press, carries out correspondence and monitors events, phenomena and ideas defining the epoch of the Enlightenment. In this regard, the scene when Asher sees a picture in a booklet informing him about an earthquake in Lisbon in 1755 seems symptomatic. This disaster definitely changed the religious beliefs of French intellectuals of the Enlightenment, again raising the question of theodi$\mathrm{cy}$, the presence of evil in the world and the inevitability of its activity. The picture shows the power of the elements of nature as well as the helplessness and loneliness of man facing its destructive power. A narrow passage of the sky appears as indifference and the resignation of God and his ominous silence. The narrator's comment reveals Asher's inner discourse, who is terrified with the number of victims and heaps of corpses, but then realises that "it is nothing exceptional. Probably nobody counted Chmielnicki's victims - all the villages, towns, cut off noble heads scattered around courtyards, Jewish women with pierced bellies" (576). The 18th-century graphic read by Asher corresponds to the anxieties of the contemporary intellectual elite, and the character is like an Eastern European Voltaire: he accepts the primacy of reason and wants to overcome the natural disaster with the assumption that the world is rational. ${ }^{4}$

Rationalistic discourse introduces the modern - pre-modern opposition, including the scientific - prescientific. In the novel, it is manifested by the category of light (575), which Asher and his father perceive entirely differently. According to his Kabbalah-practicing father, the nature of light is a kind of divine flame imprisoned in darkness. He views it in the mystic-religious context of the gnostic mode. Asher reflects on the beginning of the process of taking this spell off the world by means of empirical science. His understanding of the nature of light was formed by his studies and developed scientific discoveries. The rationalistic discourse within the novel was empowered by a fragment of Newton's tractate studied by the character, containing the defined concept as a physical phenomenon embodied with a beam of rays, where each has another refractive ability. As a doctor he mainly deals with diseases of the eyes - the organ exceptionally associated with light. Rationalistic discourse is also apparent in fragments devoted to the outbreak of a cholera epidemic in Lvov. Asher thinks of the world in scientific paradigm and, even though he does not know the stricte scientific answer to the question of the reasons for the outbreak, and he is unaware of the way and the rules of its spreading, he, nevertheless, puts forward 
scientific hypotheses and is confident that finding the answer is a matter of time. The community affected by the plague functions in the pre-modern world and remains under the power of religious discourse: "God's anger caused by people's sins is perceived as the main explanation of the plague by everybody - Jews, Christians, Turks" - Asher wonders (396).

The moment the character leaves for Vienna, the rational discourse is suspended. It only returns when the doctor reappears in the depicted world, where it reaches a kind of climax. In Vienna, he appears under the name of Ascherbach and lives with his wife Gitla-Gertrude in the modern way: they spend Sunday afternoons in a café leading disputes, reading newspapers, and writing articles to Berlinische Monatsschrift. Thusly, they join the general European discussion on the Enlightenment and the role of reason as the most precious human ability, and eventually, actively participate in discursive exchange. ${ }^{5}$ They are the only characters in the novel who gain modern subjectivity, are self-reliant and make life decisions independently of the community which they originate from.

As highlighted in the introduction, the discourses included in The Books of Jacob correspond to those in the contemporary social space and the rationalistic discourse represented by Asher reveals the features of being turned into critical postmodern discourse. Rationality as represented by Asher does not pretend to explain the whole world and does not have a totalizing character. It can be said to lack the optimism of the Enlightenment (Chaunu 1993, 257). Rationality functions here as if it went through a late-modern critical view, when the pretences of rational reason to describe the whole world and to universality were exposed and viewed as a form of establishing and holding authority. The dark side of logos is uncovered in the novel by means of the metaphor of "the light of reason" - a key term in the times of the Enlightenment (Ronduda - Szerszeń 2021, 31). Everything that is illuminated also provides shade and the brighter the light, the darker the blackout. Although the assumption is articulated as an element of Asher and his wife's discussion in the final chapters of the novel (Tokarczuk 2019, 139), in the allusive form it is interwoven with rationalistic discourse from the beginning.

By the principle of antithesis, the title of the first chapter, "On Asher Rubin and his dark thoughts" (873), refers to the metaphor of the light of reason. Foucault's renowned thesis that Western logos as developed in the 18th century dismissed everything outside the paradigm of rationality (Foucault 1987), is put to the test by Tokarczuk on the grounds of literature. The French philosopher placed madness at the antithesis of growing reason, which in rationalistic discourse began to occur as a mental disease. However, the rationalistic discourse in the novel includes the assumption that logos are helpless when faced with "the murmur of the world", i.e. with the irrational, different, transgressive, and are hard to include within the frameworks of notions and categories, or even unspeakable in rationalized language.

Crossing boundaries of rationality and irrationality can possibly be done mainly by women like Chaja, who is capable of clairvoyance and prophecy. Her state of trance is preceded by somatic symptoms and it is the reason why Asher is called to her, which only happens due to her own wishes, "because no one in this house [the Shor's 
house] believes in medicine of any kind" (Tokarczuk 2019, 869). After the physical symptoms disappear, predictions of the future appear and Asher personally experiences this "murmur of the world" as totally incomprehensible.

The meeting of Asher and Chaja is an interaction of Western logos and irrationality, of which the former phenomenon is unknown to the pre-modern world and entirely unknown to him, while the latter is positively evaluated. What emerges from the interaction of modern rationality, madness and the appropriately placed valuation marks, is critical discourse. At first Chaja goes into a trance and then she whispers into her father's ear about acquired mysteries. Asher, categorising phenomena according to empirical sciences, treats the scene as a bout of mental disease, yet he is unable to find a cure for it so he lets out some blood to lower the pressure in her veins and brain. In Chaja's world, a somatic ailment coexisting with strange behavior and unclear speech is viewed as clairvoyance and the woman gains the status of a chosen one as she is visited by "a good, holy spirit and brings her knowledge which is usually inaccessible to people" (869). Asher the rationalist is just a helpless spectator here.

\section{JACOB FRANK AND MESSIANIC DISCOURSE}

Multidiscursivity in Tokarczuk's novel includes among other things, a religious discourse. It splits into a dominant orthodox religious discourse and a messianic, heretical, socially-marginal one articulated by the figure of Jacob Frank. Both discourses enter non-obvious relations with rationality. The orthodox system, due to its orderly set of norms, rules and orders, is similar to rationality, yet, it represents a different type to the Weberian Western rationality. On the other extreme, there is messianism, particularly in the version represented by Jacob, who appears as God's madman. What the rational discourse and the messianic version represented by Jacob have in common though, is the emancipatory element.

The driving force of the rationalistic discourse at that moment in history, i.e. at the beginning of modernity, is scarce in Eastern Europe. Its emancipatory power is effective in the case of two characters: Asher and Gitla-Gertrude, who is the only woman to achieve subjectivity of the modern type. It is worth mentioning that her emancipatory path starts with the creation of a fictitious identity story. Not only does the girl claim to be a Polish princess but she also follows her made-up story, which leads her to abandoning her own community, attempting in vain to find another and eventually entering the path of an individual shaping her own life free from community pressure.

Socially liberating power is introduced by Jacob Frank's messianic discourse. In her monograph on Tokarczuk, Kantner analyzes the pragmatic side of the messianic discourse carried out by Jacob by placing him in a contemporary post-secular context $(2019,157-161)$. She mainly refers to the concept of "crypto-theology" in late-modern reflection, ${ }^{6}$ in order to outline his way of transformation. The messianic discourse introduces a radical change to the way God is spoken of. He is egalitarian, bursting with destructive energy and passion. Jacob carries out his discourse as a way to create common ground in communication with folk: "Jacob never speaks like wise men do [...], he speaks shortly and clearly, like somebody who makes a liv- 
ing as a seller at the market place or a coachman"; "[h]e especially likes blunt comparisons and does not refrain from cursing" (Tokarczuk 2019, 731, 654). This in itself releases him from the norms of orthodoxy and combined with apparent blasphemous gestures and deeds, such as the burning the Talmud, and not acting in accordance with morality in things such as eating pork which Jacob defines as Others' Deeds, but destroys the old structures. The discursive practices he applies, takes control over the Jewish community and exposed to the messianic discourse, it breaks free of Jewish orthodoxy and apparently from feudal relations as well.

The pragmatic aspect of the discourse requires a response from the community, which has to meet their expectations. The desire from part of the traditional community to leave the old structures for the world is expressed by Elisha Shor. The wishes concern the change of social status, yet they are articulated through the messianic discourse. Elisha Shor talks about the necessity of finding a fearless leader and expresses the readiness of the pre-modern religious community to let the messiah in. It is the readiness of the community to leave the old world and approach the transformation that determines the effectiveness of Jacob Frank's discourse.

The emancipatory potential of the messianic discourse has its own limitations and gradually fades away at the end of the novel, to fossilize in a locked quasi-ideological doctrine, by subordinating an individual and making him/her incapable of self-determination. The changes proceed in close connection with the history of the main character and he is the carrier of the changes. Jacob, as the lead subject, constitutes himself in a radical gesture of protest, breaking and cancelling norms and manners: "Jacob is not a wise man but a rebel" (693). He quickly and easily gains respect and creates a large group of believers who conform to his messianism and hegemonic personality: fearless, confident, suggesting that "he really knows" (654). His violent streak, tendency towards bullying and manipulation are reveal early on and in the last part of the novel he appears as a despotic leader. The liberating power of messianic discourse fades away, the sign of which is both Jacob's tyrannical dominion and overbearing manner of speech, which establishes prohibitions, orders and strict borders (183). The community, which once desired emancipation and social liberation, becomes a group of sectarian believers. The emancipation project, which messianic discourse expresses, fails and regression follows.

The kind of liberty which is an imperative of modernity, and based on the self-determination of the subject who "will eventually manage to liberate from any serfdom" (Bielik-Robson 2013, 40) did not occur. Instead of a community of free individuals, a community emerged that was subjected to the authority of the archaic-patriarchal type, in modern times dangerous and simultaneously grotesque.

\section{MOLIVDA-KOSSAKOVSKI AND MULTIDISCURSIVITY}

Certain characters comprise several discourses, the fullest and most multidimensional of which is Molivda-Kossakovski, who realizes that partially rationalistic and metaphysical as well as multicultural discourse is in opposition to ethnic discourse. A certain conflict can be observed between the multi-discursivity of Molivda and the structure of this character based on transgressions which occurs 
in several areas: regarding social-class, religion and family. Molivda functions in constant relation to difference and is situated at various frontiers, he does not fit into strict identity patterns but lets his identity flow. Although he is descended from a noble family with the historical surname Kossakovski, he takes on the nickname Molivda from one of the South-Slavonic languages. He leaves the family property and spends most of his life in constant movement. His travels around Eastern Europe, the Balkans and the Aegean seas represent something comprising vagabondage, intellectual nomadism and a spiritual journey. Although a member of the Roman Catholic Church, he marries a Jewish woman; and then continuously pursues a sense of existence and transcendental presence on the edge of various religions and beliefs, joins a Bogomil sect and later on makes friends with Jacob Frank's followers. He speaks many languages, and at least two of them as well as his mother tongue, Polish.

The discourses achieved by this transgressive character work in mutual feedback. The manner of metaphysical and rationalistic discourse connection is well illustrated by the narrator's comment on Nachman, a superb expert on Kabbalah writings, expressing Molivda's essential point of view:

When Molivda looks at Nachman [...], he is surprised that such great intelligence is used for learning such useless things. Nachman knows all extracts from books or perhaps all books by heart. [...] He spent weeks on paradoxes, comments to comments to a single unclear word in the text. He is able to pray for hours, huddled. And he knows nothing about astronomy or geography [...]. He knows nothing of political systems, governments, philosophers other than cabalists. Descartes could be for him a name for canister (Tokarczuk 2019, 480).

The above utterance includes hidden assumptions, which are essential for the discursivity of the book and the critical potential of the novel's discourse. Nachman's broad and profound Talmud and Kabbalah knowledge becomes depreciated, though Molivda values both Nachman's intelligence and his knowledge, and favours him a lot. Unexpectedly, this transgressive character accepts the point of view typical of a Polish nobleman, who, set in the east of Europe, considered himself not only a representative of Roman Catholicism, but also of Western European civilisation in general (Zajas 2008, 283). In this part Molivda becomes as if "betrayed" by the narrator, as certain, seemingly alien to him assumptions emerge here, ignoring Nachman's beliefs. Authentic and valuable knowledge of strictly scientific philosophical knowledge grows in the West of Europe, while Nachman's knowledge is just a harmless craze that does not correspond to everyday life practice in any way. Molivda takes the risk of transgression, does not fully achieve it, thus finding himself in the symbolic-cultural and social area in-between. He is still mostly determined by social-cultural background as well as by predominant assumptions, stereotypes and self-stereotypes. Not only does he value rational knowledge more, but he also applies a discourse that works within the system of exclusion and reduction. The language originating form religious system is out of place when it comes to rationalistic discourse, and seeking transcendence Molivda actualizes religiously indifferent speech in which devoted religiosity is treated as a useless burden. 
When Molivda-Kossakovski starts representing the viewpoint of a Polish nobleman, he thus raises the identity issue, expressed within Polish ethnic discourse. However, the character, due to his transgressive moves and gestures, though not always fully efficient, represents the viewpoint of a Polish nobleman only to a certain degree, more often staying in opposition to ethnic discourse. Molivda's crossing various boundaries: geographic, political, social, mental, setting up relations with what is different lets him represent contemporary multicultural discourse. The discourse, as Krzysztof Zajas reminds us, "is in majority an opposition and response to a discourse of nationalism" $(2008,278)$ and is based on seeking similarities in the different, instead of exposing differences. Molivda also creates a counter-discourse to Polish-centric discourse, particularly its national-Catholic or patriotic-martyrdom components. The latter two appear in utterances of the colonel, Molivda's brother, and are immediately subjected to a critical view. The disagreement (and hostility at times) between nationalistic and multicultural discourses, which in the novel are reflected in the orthodox and in the heretic discourses, reveals itself on the level of characters' speeches accompanied by the narrator's comments. Molivda's question of why not to guarantee some rights to infidels in the Polish Republic receives indignation as a response of his brother. He is not convinced with Molivda's life experience, either:

"Wherever I stepped in the world," Molivda says, "I saw that maybe God is one, yet, there are numerous ways to believe in Him, an infinite number... In various kinds of shoes you may walk towards God..."

"This is what you should not speak of," his brother reprimands. "It is a disgrace to your honour. Fortunately, your past misdeeds have been almost forgotten." He folds his mouth as if he wanted to spit (Tokarczuk 2019, 244-245).

The rules followed by nationalistic discourse are based on the old (rather archaic) familiar-alien structure, which contains a strong component of exclusion to those incompatible with the recently-developed imagined community. Multicultural discourse smooths away this opposition and introduces me - the other structure, instead. In this structure, the emancipating individual subjectivity is empowered and becomes strong enough to broaden the area, free from community bonds. Molivda feels better in Smyrna than in Warsaw, and while living among Frank's followers, he identifies with them. On the other hand, having returned to the royal chambers, he resurrects his previous identity of the Polish nobleman. However, a full return to the inherited identity is impossible and Molivda remains on the border of several culturally-symbolic worlds. The narrator's discursive utterances, in turn, regarding Molivda's viewpoint, include the character in the critical discourse of the novel. It is from this character's view that the idea of the necessity to introduce rights for others, as such was the spirit of the times, i.e. the age of Enlightenment, is actually uttered. It can hardly be unnoticed that the same "air of the times" pervades our contemporary times, too.

\section{CONCLUSION}

Individual literary characters, their utterances, viewpoints and unspoken assumptions work towards the specific discourse included in the novel and determine its multi-discursivity. The interaction of social discourses and the literary discourse gen- 
erates knowledge about the beginnings of modernity in remote peripheries, about the rise of modern ways of structuring the world based on national grounds. It refers to the forming of modern subjectivity together with the development of Western rationality, and also about the winding paths of emancipation undergoing in the East of Europe.

Not many among the community of Jacob Frank's believers can be considered an exemplification of the Eastern European path to modernity with the emancipation of the individual imperative included. "A cute little girl" appears in the latter part of the novel, Marynia Wołowska playing Haydn on the spinet (30). In the future the girl will become Maria Szymanowska, a talented pianist and composer playing concerts in the most important European capitals. A 19th-century descendant of the Shor family, leading the life of an independent woman, allowed her ancestor Elish Shor's dreams of entering the world to come absolutely true. Renowned and admired, she contributed to the creation of European music, ran an artistic drawing room in St. Petersburg and designed her life independently of social and family matters. This is highlighted by her leaving her husband and bringing up her children by herself.

The novel also plays the role of a critical discourse connected with contemporary discussions, e.g. on the shape of traditions in the First Polish Republic or on national identity. As critical discourse, it reveals assumptions, stereotypes and self-stereotypes about religious or national tolerance in the First Polish Republic, which by the 18th century had not been a tolerant place for a long time. The critical discourse appears at the level of the narrator's speech, but is, to a great extent, formed thanks to Molivda-Kossakovski, as a transgressive figure. It is from his point of view that the ethnocentric mode of speaking about the past is questioned, the sense of preserving the my own-other structure is denied and the dogmatic nature of strict identity patterns is revealed.

The novel taken as a discourse conveys the content, which in a Polish-centric viewing of the past is not mentioned or denied. The content discussed solely in the novel by the characters is the social-economic and symbolically-cultural power of Polish Catholic nobility in the south-eastern territory, where the majority of people were Christian Orthodox, Greek Catholic or Judaic, and used languages other than Polish on a daily basis. When one of the characters exclaims: "Does anyone here speak Polish?" (883), she therefore reveals the inadequacy of assumptions about the Polish character of the area and points to the historical truth, which was that there were areas in the First Polish Republic where Polish speaking inhabitants were a minority.

Discursivity in Olga Tokarczuk's novel allows us to situate it in a broad area of discursive circulation, where the process of reversing its own tradition occurs. This area is created by other literary texts, numerous academic works ${ }^{7}$ and public debates, in which the author participates and speaks her mind. ${ }^{8}$ In the novel, her voice is divided between the narrator and the characters, whose utterances create a meeting place for social and novelistic discourses.

Translated from Polish by Małgorzata Kołodzińska 
1 All references including page numbers concern the Polish second printing of the first edition. All quotations from Polish have been translated by the translator of the study Małgorzata Kołodzińska.

2 The concept of literature as a constitutive character was put forward by the French researcher Dominique Maingueneau and means that literary discourse does not require any external validation (2015, 79-84).

3 Discourse is the essential category in Katarzyna Kantner's scientific monograph on Olga Tokarczuk's works (2019).

4 The Polish-French thinker Bronisław Baczko interestingly wrote about Voltaire's response to the earthquake in Lisbon (2001, 15-21).

5 At the same time, in 1784, Kant's famous essay "Was ist Aufklärung?" (What is Enlightenment?) is published (1966, 164-172).

6 The presence of the messianic idea in contemporary philosophy is studied by philosopher Agata Bielik-Robson (2008).

7 Critical discourse of Polish-centric approach to the past in the First Polish Republic appears to be based on literary studies and historiography (Romanowski 2007; Sowa 2011).

8 A bibliography of the writer's public speeches can be found in Kantner's monograph (2019, 309-310).

\section{LITERATURE}

Baczko, Bronisław. 2001. "Wolter: rozumny ład i zło moralne" [Voltaire: reasonable order and moral evil]. In Hiob, mój przyjaciel. Obietnice szczęścia i nieuchronność zła [Hiob, my friend. Promises of happiness and the inevitability of evil], Bronisław Baczko, trans. by Jerzy Niecikowski, 15-77. Warsaw: Wydawnictwo PWN.

Bielik-Robson, Agata. 2008. "Na pustyni": Kryptoteologie późnej nowoczesności ["In the desert": Crypto-theologies of late modernity]. Krakow: Universitas.

Bielik-Robson, Agata 2013. "Cogito albo narodziny nowoczesności z ducha gnostyckiego paradoksu: Hansa Blumenberga lektura Kartezjusza" [Cogito or the birth of modernity from the spirit of gnostic paradox: Hans Blumenberg's reading of Descartes]. In Deus otiosus: Nowoczesność w perspektywie postsekularnej [Deus otiosus: Modernity in postsecular perspective], ed. by Agata Bielik-Robson Maciej A. Sosnowski, 39-89. Warsaw: Wydawnictwo Krytyki Politycznej.

Chaunu, Pierre. 1993. Cywilizacja wieku Oświecenia [Civilisation of the age of Enlightenment). Trans. by Eligia Bąkowska. Warsaw: PIW.

Foucault, Michel. 1987. Historia szaleństwa $w$ dobie klasycyzmu [The history of madness in the age of classicism]. Trans. by Helena Kęszycka. Warsaw: PIW.

Foucault, Michel. 2002. Porzadek dyskursu [The order of discourse]. Trans. by Michał Kozłowski. Gdańsk: słowo/obraz/terytoria.

Fowler, Roger. 1989. "Założenia socjologicznej teorii 'dyskursu literackiego"' [Assumptions of sociological theory about "literary discourse"]. Trans. by Maria Bożenna Fedewicz. Pamiętnik Literacki 3 : 305-336.

Habermas, Jürgen. 2000. Filozoficzny dyskurs nowoczesności [The philosophical discourse of modernity]. Trans. by Małgorzata Łukasiewicz. Krakow: Universitas.

Kant, Immanuel. 1966. "Co to jest Oświecenie?" [What is Enlightenment?]. Trans. by Adam Landman. In Kant, ed. by Tadeusz Kroński, 164-172. Warsaw: Wiedza Powszechna.

Kantner, Katarzyna. 2019. Jak działać za pomoca słów? Proza Olgi Tokarczuk jako dyskurs krytyczny [How to work with words? Olga Tokarczuk's prose as a critical discourse]. Krakow: Universitas.

Kasperski, Edward. 1998. "Między poetyką i antropologią postaci: Szkic zagadnień" [Between poetics and anthropology of characters: The outline of questions]. In Postać literacka: Teoria i historia [Literary character: Theory and history], ed. by Edward Kasperski - Brygida Pawłowska-Jądrzyk, 9-41. Warsaw: Warsaw University. 
Maingueneau, Dominique. 2015. "Dyskurs literacki jako dyskurs konstytuujący” [Literary discourse as a constitutive discourse]. In Dyskurs literacki: Paratopia i scena wypowiedzenia [Literary discourse: Paratopia and the scene of utterance], Dominique Maingueneau, trans. by Hanna Konicka, 79-92. Warsaw: Instytut Badań Literackich.

Romanowski, Andrzej. 2007. Prawdziwy koniec Rzeczy Pospolitej [The real end of the first Polish Republic]. Krakow: Universitas.

Ronduda, Łukasz - Tomasz Szerszeń, eds. 2021. Oświecenie, czyli tu i teraz [Enlightenment or here and now]. Krakow - Warsaw: Wydawnictwo Karakter.

Sowa, Jan. 2011. Fantomowe ciało króla: Peryferyjne zmagania z nowoczesna forma [The king's phantom body. The peripheral struggle with modern forms]. Krakow: Universitas.

Tokarczuk, Olga. [2014] 2019. Księgi Jakubowe. Reprint of the 1st edition. Krakow: Wydawnictwo Literackie.

Weber, Max. 1995. Szkice z socjologii religii [Sketches of sociology of religion]. Trans. by Jerzy Prokopiuk - Henryk Wandowski. Warsaw: Książka i Wiedza.

Zajas, Krzysztof. 2008. "Dyskursy w cyrkulacji”" [Discourses in circulation]. In Nieobecna kultura: Przypadek Inflant Polskich [Absent culture: The case of Polish Livonia), Krzysztof Zajas, 272-279. Krakow: Universitas.

\title{
Literary characters and interdiscursivity in the novel "The Books of Jacob" by Olga Tokarczuk
}

Literary characters. Social discourses. Literary discourse. Olga Tokarczuk.

This article includes an analysis of selected characters in The Books of Jacob (Ksiegi Jakubowe [2014] 2019) by Olga Tokarczuk from the context of discourse. The analysis is based on the concept of literary characters as the "common ground" for a discourse in literature, existing within the Polish theory of literature, as well as a discourse on extra-literary reality. In Tokarczuk's novel, there is a clash of two major discourses: rationalistic and metaphysical-messianic. The former appears at times as scientific-medical, represented by one of the background characters, Rubin Asher. The character is the quickest to emancipate himself, in his community, impersonating the modernity and rationality of the Enlightenment. The character who plays the role of the "common ground" for metaphysical-messianic discourse is Jacob Frank. Molivda-Kossakovski is situated at the intersection of several discourses. His multi-discursivity combines rationalistic, metaphysical, ethnic and multi-cultural discourses, of which the latter plays a critical role for the former ethnic one. The interdiscursivity of the work puts forward the knowledge of the origins of modernity in remote periphery, of the beginnings of modern ways of world categorization and generates critical discourse.

\author{
Walentyna Krupowies, $\mathrm{PhD}$ \\ Institute of Linguistics and Literary Studies \\ Siedlce University of Natural Sciences and Humanities \\ Konarskiego str. 2 \\ $01-110$ Siedlce \\ Poland \\ vakru@onet.eu \\ ORCID: https://orcid.org/0000-0003-1013-7708
}

